\title{
Thyroid hormone and retinoic acid induce the synthesis of insulin-like growth factor-binding protein- 4 in prepubertal pig Sertoli cells
}

\author{
G Bardi, C Bottazzi, I Demori and S Palmero \\ Dipartimento di Biologia Sperimentale, Ambientale ed Applicata, Sezione di Fisiologia Generale e Comparata, Università degli Studi di Genova, \\ Genoa, Italy \\ (Correspondence should be addressed to S Palmero, Dipartimento di Biologia Sperimentale, Ambientale ed Applicata, Sezione di Fisiologia \\ Generale e Comparata, Università degli Studi di Genova, Corso Europa, 26, 16132 Genova, Italy; Email: spalmero@csita.unige.it)
}

\begin{abstract}
A large body of evidence suggests the existence of an intratesticular IGF system complete with ligands, receptors and binding proteins (IGFBPs); the aim of the present study was to evaluate tri-iodothyronine $\left(\mathrm{T}_{3}\right)$ and retinoic acid (RA) effects on IGFBP production by Sertoli cells. A significant dose-dependent increase in IGFBP-4 mRNA levels was observed in Sertoli cells cultured in the presence of physiological concentrations of $\mathrm{T}_{3}$ or RA. This response was inhibited by cycloheximide, indicating that de novo protein synthesis is required, as well as by actinomycin D, suggesting that the increase in mRNA levels requires transcriptional activation. As shown by ligand blot assays the stimulatory effects of both agents on IGFBP-4 mRNA expression appears to be consistent with an enhanced synthesis and secretion of IGFBP-4, thus suggesting that the transcriptional response is transduced to the protein level. Our data establish an important direct role for $\mathrm{T}_{3}$ and RA in regulating IGFBP-4 expression and consequently IGF activity at the testis level.
\end{abstract}

European Journal of Endocrinology 141 637-643

\section{Introduction}

Thyroid hormone plays an important role in the regulation of normal testis development (for review see 1). An early and critical influence of thyroid status on Sertoli cell morphofunctional maturation and proliferation $(2-5)$ as well as on testis growth $(6-8)$ has been established. The exact role of thyroid hormone in the control of testis function, however, is not fully understood.

Specific cellular effects of thyroid hormone on target tissues are mediated by the interaction of the hormone with nuclear receptors that bind to regulatory regions of genes and modify their expression.

The presence of thyroid hormone receptors in Sertoli cells has been proved $(9,10)$ and, as regards genomic actions, a direct regulation of thyroid hormone on the Sertoli cell expression of androgen binding protein (11), glucose transporter isoform 1 (12), Mullerianinhibiting substance (13), clusterin/inhibin (14) and collagen/entactin (15) mRNAs has been reported.

The aim of our previous and present research work was to evaluate the possible involvement of the insulinlike growth factor (IGF) system in mediating thyroid hormone effects at the Sertoli cell level. Actually the testis harbours a complete IGF system replete with ligand, receptor and IGF-binding proteins (IGFBPs), and Sertoli cells are known to produce IGF-I, a powerful mitogenic and differentiating factor, which may play a fundamental role in the paracrine/autocrine regulation of testis development and function (16).

The effects of IGF-I are mediated by specific IGF receptors and modulated by IGFBPs. Currently, six IGFBPs have been cloned and sequenced. IGFBPs have been proposed to act as modulators of IGF by either potentiating or inhibiting the actions of the growth factor (for reviews see 17, 18).

The aim of the present study was to establish whether tri-iodothyronine $\left(\mathrm{T}_{3}\right)$ can directly affect IGFBP expression in cultured Sertoli cells. We also tested the possible involvement of retinoic acid (RA), which is known to have an impact on Sertoli cell physiology (19) and to act via nuclear receptors belonging to the steroid/ thyroid hormone receptor superfamily.

In our experiments we utilised primary cultures of porcine Sertoli cells, which have been previously demonstrated to be a suitable and useful model for the study of thyroid hormone effects at the testis level. Actually, nuclear $\mathrm{T}_{3}$ receptors have been characterised in Sertoli cells isolated from prepubertal piglet testes 
(20); moreover, in these cells thyroid hormone has been shown to significantly increase the production of transforming growth factor $\beta$-like protein (21) and the rate of protein synthesis $(22)$.

\section{Materials and methods}

\section{Cell isolation and culture}

Sertoli cells, obtained from 2- to 3-week-old piglet testes, were prepared and purified as previously described (23). Cells were plated at a density of $10^{7} / 10 \mathrm{ml}$ per dish (diameter $100 \mathrm{~mm}$ ) and cultured at $32^{\circ} \mathrm{C}$ in a humidified atmosphere of $5 \% \mathrm{CO}_{2}$, in (1:1) Dulbecco's modified Eagle's/Ham's F12 medium (Grand Island Biological Co., Grand Island, NY, USA) containing $1.2 \mathrm{mg}$ sodium bicarbonate $/ \mathrm{ml}, 15 \mathrm{mmol} / \mathrm{l}$ Hepes and $20 \mu \mathrm{g}$ gentamicin $/ \mathrm{ml}$; this medium was supplemented with transferrin $(5 \mu \mathrm{g} / \mathrm{ml})$ and vitamin $\mathrm{E}(10 \mu \mathrm{g} / \mathrm{ml})$. During the first $24 \mathrm{~h}$ in culture Sertoli cells were maintained in the presence of $0.5 \%(\mathrm{v} / \mathrm{v})$ foetal calf serum. Therewith Sertoli cells were cultured for 1 day in control medium and for an additional 1-2 days in the presence or absence of physiological concentrations of $\mathrm{T}_{3}$ or RA.

$\mathrm{T}_{3}$ and RA were added to the culture medium at the indicated concentrations. The protein synthesis inhibitor cycloheximide (CEX) and the transcription inhibitor actinomycin D (ActD) were added to the cultures at a concentrations of 0.1 and $5 \mu \mathrm{g} / \mathrm{ml}$ respectively. To minimise side-effects by translational or transcriptional inhibition, the incubation time was reduced to $6 \mathrm{~h} . \mathrm{T}_{3}$, RA, CEX, ActD, transferrin and vitamin E were supplied by Sigma Chemical Co., St Louis, MO, USA.

\section{RNA isolation}

Total RNA was prepared using acid guanidinium thiocyanate-phenol-chloroform extraction (24). RNA was quantified by measuring the absorbance at 260 nm. Samples were stored at $-80^{\circ} \mathrm{C}$ until used.

\section{cDNA probes}

The rat IGFBP-1 (25), -2 (26), -3 (27), -4 (28), -5 (29) and -6 (30) cDNA probe was kindly provided by Dr S Shimasaki, Department of Cell Biology, The Scripps Research Institute, La Jolla, CA, USA. The rat $18 \mathrm{~S}$ rDNA probe (BamHI-HindIII fragment) (31) was generously provided by Dr I G Wool, Department of Biochemistry and Molecular Biology, The University of Chicago, Chicago, IL, USA. The probes were labelled to high specific activity by multiprime DNA labelling systems (Amersham International plc, Amersham, Bucks, UK) using $\left[{ }^{32} \mathrm{P}\right] \mathrm{dCTP}$ (NEN Du Pont, Du Pont De Nemours $\mathrm{GmbH}$, Bad Homburg, Germany; specific radioactivity $3000 \mathrm{Ci} / \mathrm{mmol}$ ).

\section{Northern blot analysis}

Total RNA $(20 \mu \mathrm{g})$ was fractionated by loading on $1 \%$ agarose gel containing $2.2 \mathrm{~mol} / \mathrm{l}$ formaldehyde in $20 \mathrm{mmol} / \mathrm{l}$ 3-[N-morpholino]propanesulfonic acid (pH 7.0), $5 \mathrm{mmol} / \mathrm{l}$ sodium acetate and $1 \mathrm{mmol} / \mathrm{l}$ $\mathrm{Na}_{2}$ EDTA. RNA was stained with ethidium bromide to check for the integrity of the samples and for equal loading in each lane. After transfer to nylon membranes by capillary blotting, prehybridisation was performed for $2 \mathrm{~h}$ at $42{ }^{\circ} \mathrm{C}$ in a solution containing $5 \times$ SSPE $\left(1 \times \mathrm{SSPE}=0.15 \mathrm{~mol} / \mathrm{l} \quad \mathrm{NaCl}, \quad 0.01 \mathrm{~mol} / \mathrm{l} \quad \mathrm{NaH}_{2} \mathrm{PO}_{4}\right.$, $1 \mathrm{mmol} / \mathrm{l} \mathrm{EDTA}$ ), $50 \%$ formamide, $5 \times$ Denhardt's solution, $0.5 \%$ SDS and $100 \mu \mathrm{g} / \mathrm{ml}$ denatured salmon sperm DNA (32). Hybridisation was carried out for $20 \mathrm{~h}$ at $42{ }^{\circ} \mathrm{C}$ in fresh buffer containing the ${ }^{32} \mathrm{P}$-labelled probe. After hybridisation, the filters were washed sequentially in $2 \times, 1 \times$ and $0.1 \times$ SSPE, $0.1 \%$ SDS at $42^{\circ} \mathrm{C}$, each wash lasting for $20 \mathrm{~min}$. Filters were then exposed to Amersham Hyperfilm-MP films at $-80^{\circ} \mathrm{C}$ using intensifying screens.

To ensure even loading, the membranes were stripped and rehybridised with a rat $18 \mathrm{~S}$ rDNA probe.

The signal intensity of the autoradiograms was quantified by scanning densitometric analysis using the Scion Image software package (Scion Corporation, USA). Arbitrary densitometric units were normalised to $18 \mathrm{~S}$ and expressed as a percentage of the control values.

\section{Ligand blotting}

Sodium $\left[{ }^{125}\right.$ I]iodide (carrier-free) was purchased from Amersham. Recombinant human IGF-I (lot no. 810288) was a gift from Novartis Pharma AG (Basel, Switzerland). IGF-I was iodinated by the chloramine-T method to a specific activity of approximately 60$80 \mu \mathrm{Ci} / \mu \mathrm{g}$.

For ligand blotting, samples were analysed according to Hossenlopp et al. (33) with slight modifications. Briefly $150 \mu \mathrm{g}$ protein from supernatant medium were separated on $10 \%$ SDS-PAGE under non-reducing conditions and transferred to nitrocellulose. Membranes were blocked overnight at $4{ }^{\circ} \mathrm{C}$ in $0.9 \% \mathrm{NaCl}, 50 \mathrm{mmol} / \mathrm{l}$ Tris- $\mathrm{HCl}$ (pH 7.4), $0.5 \%$ fish gelatine, followed by incubation with ${ }^{125}$ I-IGF-I $\left(5-10 \times 10^{6}\right.$ c.p.m. $)$ at $4{ }^{\circ} \mathrm{C}$ for $24 \mathrm{~h}$ in $0.9 \% \mathrm{NaCl}, 50 \mathrm{mmol} / \mathrm{l}$ Tris- $\mathrm{HCl}(\mathrm{pH} \mathrm{7.4})$, $0.5 \%$ fish gelatine, $0.2 \%$ NP-40. After washing, membranes were air-dried and exposed for $24 \mathrm{~h}$ at $-80^{\circ} \mathrm{C}$ to $\mathrm{X}$-ray films. The signal intensity of the autoradiograms was quantified by scanning densitometric analysis using the Scion Image software package.

\section{Data analysis}

The experiments reported here were repeated at least two or three times with independent cell preparations. A representative experiment of each series is presented; data are given as mean \pm s.E.M. Statistical significance 
was analysed using ANOVA with the multiple group comparison test of Scheffé. Differences are accepted as significant at $P \leq 0.05$.

\section{Results}

Preliminary analyses demonstrated that in cultured Sertoli cells IGFBP-2, $-3,-4$ and -5 messages were clearly expressed whereas IGFBP-1 and -6 mRNAs were not detected or barely detectable.

A significant increase in IGFBP-4 mRNA levels was observed in Sertoli cells cultured in the presence of physiological concentrations of $\mathrm{T}_{3}$ or RA.

Figure 1 shows the result of Northern blotting experiments. Compared with the respective controls, the induction of IGFBP-4 mRNA was detectable at all time points studied. As observed in the time course assays IGFBP-4 mRNA levels in Sertoli cells cultured in the presence of $T_{3}$ reached a maximum between 6 and $12 \mathrm{~h}$, while in RA-exposed cells the highest amount of the specific transcript was detectable between 12 and $24 \mathrm{~h}$.

The dose-response curves of the effects of $\mathrm{T}_{3}$ and RA on IGFBP-4 mRNA expression are illustrated in Fig. 2; the maximum response to thyroid hormone occurred at concentrations ranging from $10^{-8}$ to $10^{-10} \mathrm{~mol} / \mathrm{l}$, whereas the maximum increase in IGFBP-4 mRNA level was elicited by RA at a concentration of $10^{-7}$ / $10^{-8} \mathrm{~mol} / \mathrm{l}$. No synergistic or additive effects of the two agents on IGFBP-4 expression were observed (data not shown).

To establish whether increased levels of IGFBP-4 mRNA depend on transcriptional activation or to a greater stability of the messages, the effects of the transcriptional inhibitor ActD were tested. Moreover, to further investigate whether the stimulation of IGFBP-4 mRNA requires de novo protein synthesis, CEX was used as an inhibitor. As shown in Fig. 3, ActD and CEX both prevented the stimulation of IGFBP-4 mRNA expression by $\mathrm{T}_{3}$ and RA.

IGFBP levels in conditioned medium of hormonally treated Sertoli cells were evaluated by ligand blotting. As shown in Fig. 4, the addition of $\mathrm{T}_{3}$ and RA resulted in a dramatic increase in the production of an IGFbinding protein with a molecular mass of about $24 \mathrm{kDa}$ corresponding to IGFBP-4 (34-36); a second major band of $29 \mathrm{kDa}$, probably representing the glycosylated form of IGFBP-4 (37), was also detected.

\section{Discussion}

A large body of evidence demonstrates the existence of an intratesticular IGF system complete with ligands, receptors and binding proteins (38). Within the testis the Sertoli cell has been proposed to be a site of IGF-I production (39), reception $(40)$ and action $(41,42)$ as well as of IGFBP generation (43). The intratesticular
(A)

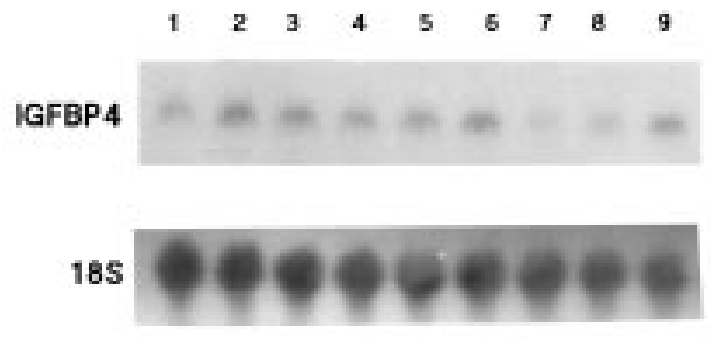

(B)

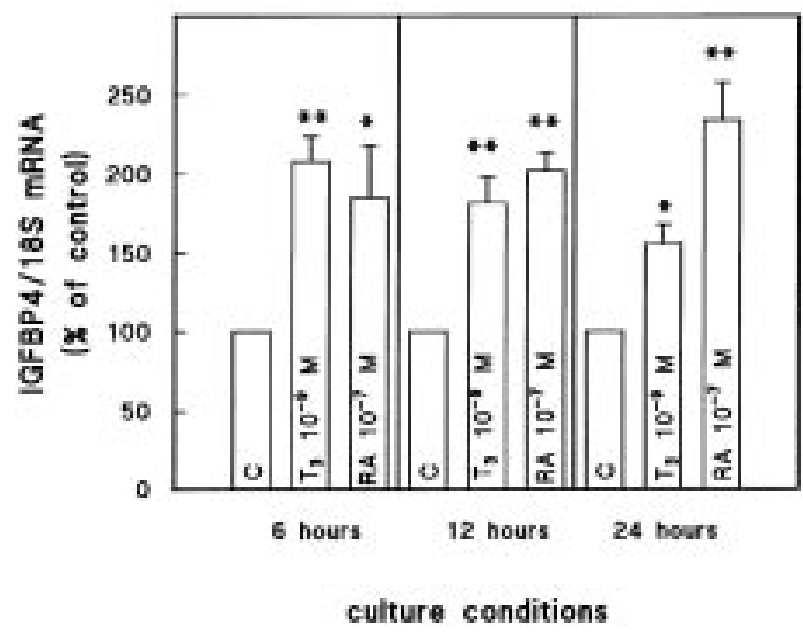

Figure 1 Time course of $T_{3}$ and RA effects on IGFBP-4 mRNA levels in immature pig Sertoli cells cultured for different times in the presence or absence of hormones. (A) Representative autoradiograms of Northern blots showing IGFBP-4 mRNAs. As a control to ensure even loading, hybridisation using an $18 \mathrm{~S}$ probe was performed. (B) Densitometric quantification of IGFBP-4 Northern blots after normalisation to 18S. Data are given as a percentage of the control value. Values are the mean \pm S.E.M. of three separate experiments. ${ }^{*} P \leq 0.05,{ }^{* *} P \leq 0.01$ (treated vs control).

IGF system appears to be under a complex regulation by endocrine and paracrine factors (16) not fully understood. On the one hand, previous evidence has suggested that the IGF system is a target for thyroid hormone in both the new-born and adult rat (44-47); on the other hand thyroid hormone as well as RA is known to be essential for normal testis development $(1,19)$ and $\mathrm{T}_{3}$ has been proved to significantly increase IGF-I production by immature rat Sertoli cells (48).

IGF action is mediated by specific receptors and modulated by IGFBPs (17); despite many similarities, the different IGFBPs have distinct structural and functional properties, which together with differences in their tissue and developmental expression, determine the individual regulatory roles of the different IGFBPs (18). 
[A]

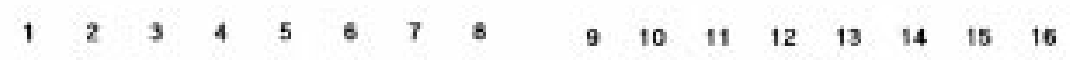

IGFBP4

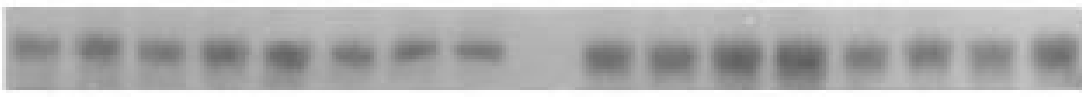

$18 \mathrm{~s}$

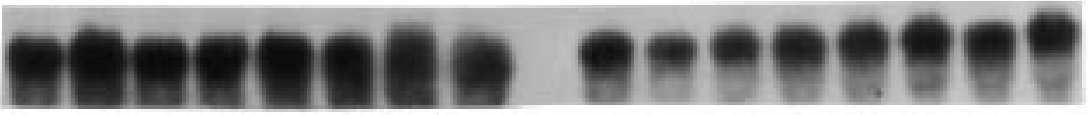

(B)

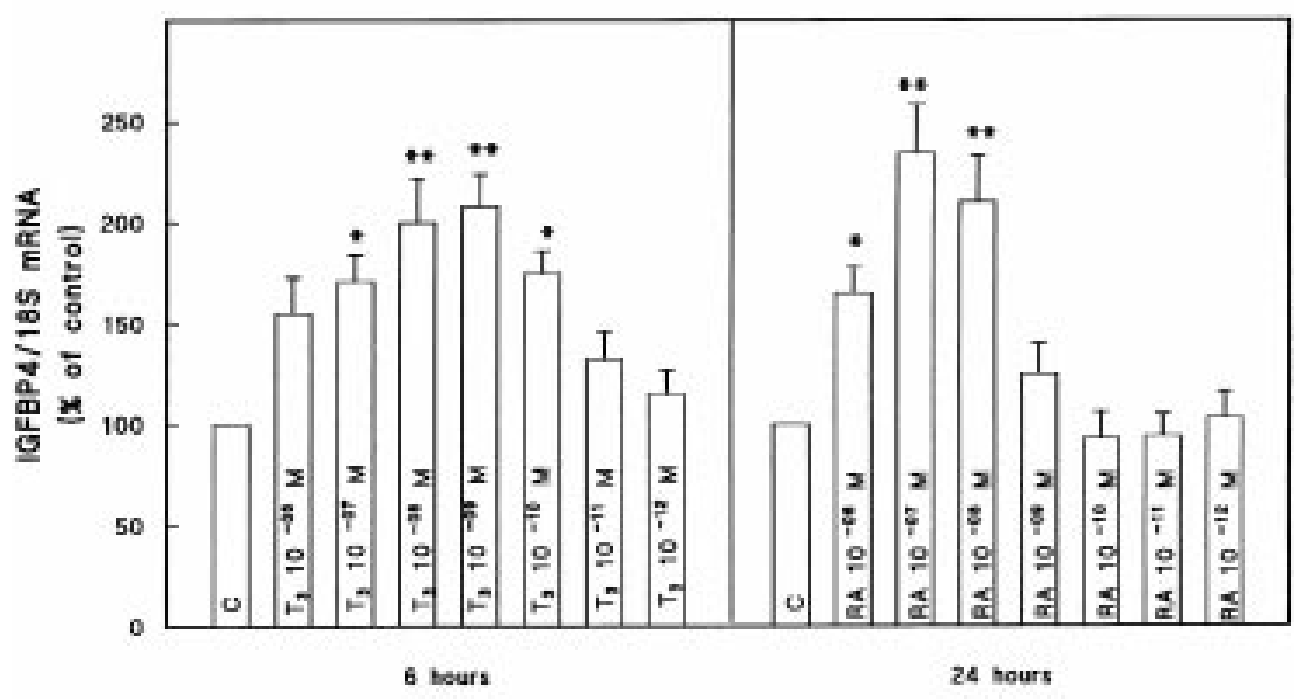

culture conditions

Figure 2 Dose dependence of $T_{3}$ and RA effects on IGFBP-4 mRNA levels in immature pig Sertoli cells cultured in the presence or absence of different concentrations of hormones. (A) Representative autoradiograms of Northern blots showing IGFBP-4 mRNAs. As a control to ensure even loading, hybridisation using an $18 \mathrm{~S}$ probe was performed. (B) Densitometric quantification of Northern blots after normalisation to $18 \mathrm{~S}$. Data are given as a percentage of the control value. Values are the mean \pm S.E.M. of three separate experiments. ${ }^{*} P \leq 0.05,{ }^{* *} P \leq 0.01$ (treated vs control).

In this study we employed Sertoli cell primary cultures isolated from immature piglet testes to analyse the possible direct effect of $\mathrm{T}_{3}$ and/or RA on IGFBP gene expression.

Our data establish a direct role for $\mathrm{T}_{3}$ and RA in regulating IGFBP-4 expression at the Sertoli cell level. Actually, both agents induced a significant dosedependent increase in IGFBP-4 mRNA levels over all time points tested. Such an increase requires new transcription, since it was abolished by the presence of ActD in the culture medium along with hormones. On the other hand, the CEX inhibition of $\mathrm{T}_{3}$ and RA stimulation indicates that de novo protein synthesis is required, suggesting the involvement of a hormoneinduced regulatory protein to enhance IGFBP-4 mRNA expression.
As shown by ligand blot assays the hormonedependent increase in IGFBP-4 mRNA levels appears to be consistent with an enhanced synthesis and secretion of IGFBP-4, thus suggesting that the transcriptional response is transduced to the protein level.

A similar $\mathrm{T}_{3}$-increased IGFBP-4 expression has been recently reported in cultured rat hepatocytes and is consistent with in vivo experiments demonstrating an increase in serum IGFBP-4 levels in $\mathrm{T}_{3}$-treated rats (36). In addition, previous studies showed the specific stimulation of IGFBP-4 expression by $\mathrm{T}_{3}$ and/or RA in human breast cancer cell lines (49) and mouse osteoblasts (35).

Taken together these results suggest a possible direct regulation of the IGFBP-4 gene by both $\mathrm{T}_{3}$ and $\mathrm{RA}$ via their nuclear receptors, probably through a common receptor-binding site within the IGFBP-4 promoter. 
(A)

$$
\begin{array}{lllllllll}
1 & 2 & 3 & 4 & 5 & 5 & 7 & 8 & 9
\end{array}
$$

IGFBP4

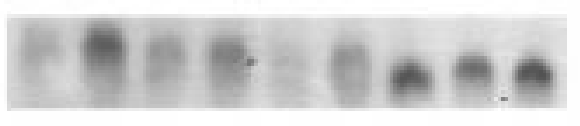

185

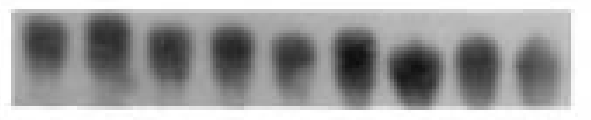

(B)

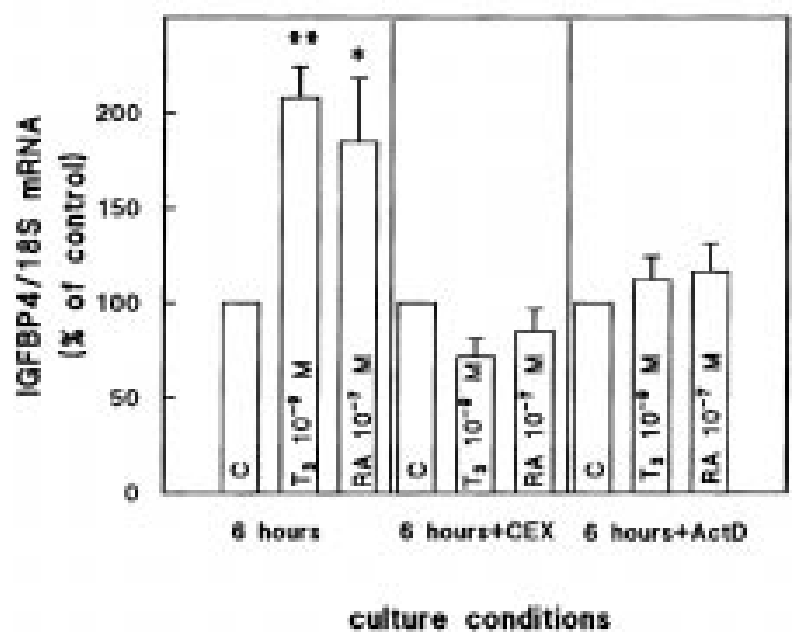

Figure 3 Translational (CEX) and transcriptional (ActD) inhibition of $\mathrm{T}_{3}$ and RA effects on IGFBP-4 mRNA levels in immature pig Sertoli cells cultured under different experimental conditions. (A) Representative autoradiograms of Northern blots showing IGFBP-4 mRNAs. As a control to ensure even loading, hybridisation using an $18 \mathrm{~S}$ probe was performed. (B) Densitometric quantification of Northern blots after normalisation to 18S. Data are given as a percentage of the control value. Values are the mean \pm S.E.M. of three separate experiments. ${ }^{*} P \leq 0.05,{ }^{* *} P \leq 0.01$ (treated vs control).

Actually, the thyroid hormone receptor and RA receptor are structurally similar and can bind as homodimers or heterodimers to a single synthetic DNA response element, acting as ligand-dependent transcription factors $(50,51)$. Both receptors belong to the steroid/thyroid hormone receptor superfamily, and interestingly one progesterone receptor-binding site has been localised in the rat IGFBP-4 gene $5^{\prime}$-flanking region (52).

The IGFBPs are known to act as modulators of the IGF system by either potentiating or inhibiting IGF action. Although its physiological role is still unclear, IGFBP-4 appears to inhibit IGF mitogenic actions under most experimental conditions, suggesting that it is an important negative regulator of cellular proliferation $(17,53)$. A major factor regulating IGFBP action is its
(A)

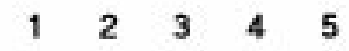

\section{$29 \mathrm{kDa}$}

$24 \mathrm{kDa}$

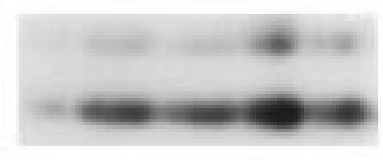

(B)

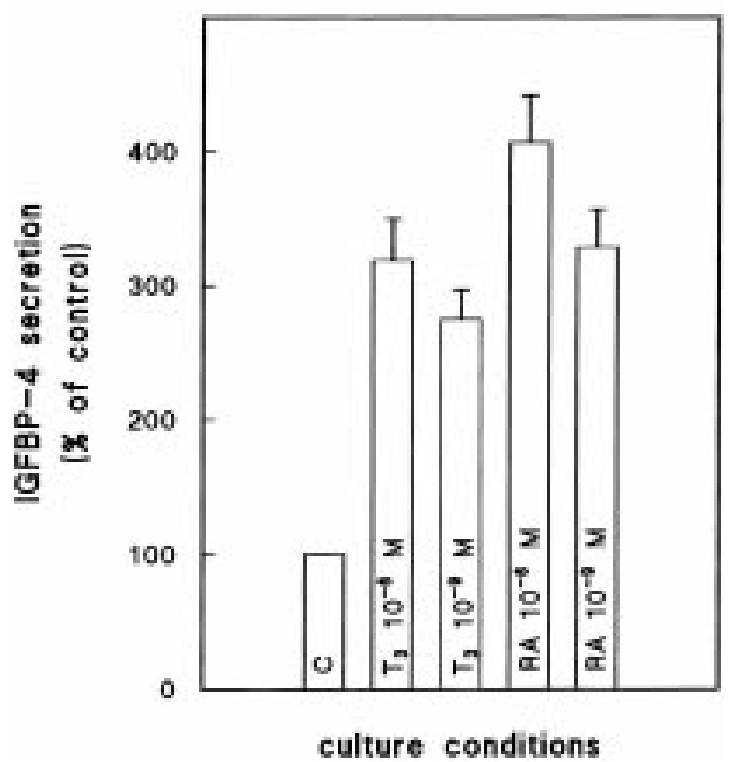

Figure 4 Effects of $T_{3}$ and RA on IGFBP-4 production by immature pig Sertoli cells cultured for $24 \mathrm{~h}$ in the presence or absence of hormones. (A) Representative autoradiograms of ligand blots showing IGFBP-4 levels in the conditioned medium of Sertoli cells cultured under different experimental conditions.

(B) Densitometric quantification of ligand blots after normalisation for protein loading. Data are given as a percentage of the control value. Values are the mean \pm S.E.M. of two separate experiments. (treated vs control: $P \leq 0.05$ ).

distribution between the soluble phase (interstitial fluid) and the extracellular matrix (ECM) or cell surface; inhibitory effects of IGFBP on IGF action are associated typically with high-affinity soluble forms. IGFBP-4 acts exclusively as an inhibitor of IGF action, because it does not associate with ECM components or the cell surface (18).

Our previous study suggested the involvement of IGF-I in mediating testicular effects of thyroid hormone (48). The present results strongly suggest a direct role for thyroid hormone in regulating IGFBP-4 expression and consequently in modulating IGF activity at the gonadal level. 


\section{Acknowledgements}

The authors are greatly indebted to Prof. E Fugassa for her helpful advice and encouragement during the course of the experiments. This research was supported by a grant from the Ministero Università e Ricerca Scientifica Technologica, Rome, Italy.

\section{References}

1 Jannini EA, Ulisse S \& D'Armiento M. Thyroid hormone and male gonadal function. Endocrine Reviews 199516 443-459.

2 Palmero S, de Marchis M, Gallo G \& Fugassa E. Thyroid hormone affects the development of Sertoli cell function in the rat. Journal of Endocrinology 1989123 105-111.

3 Francavilla S, Cordeschi G, Properzi G, Jannini EA, Palmero S, Fugassa E et al. The effect of thyroid hormone on prenatal and postnatal development of the rat testis. Journal of Endocrinology $199112935-42$.

4 Van Haaster LH, De Jong FH, Docteur R \& De Rooij DG. High neonatal triiodothyronine levels reduce the period of Sertoli cell proliferation and accelerate tubular lumen formation in the rat testis, and increase serum inhibin levels. Endocrinology 1993133 755-760.

5 Palmero S, Prati M, Bolla F \& Fugassa E. Tri-iodothyronine directly affects rat Sertoli cell proliferation and differentiation. Journal of Endocrinology 1995145 355-362.

6 Cooke PS \& Meisami E. Early hypothyroidism in rats causes increased adult testis and reproductive organ size but does not change testosterone levels. Endocrinology 1991129 237-243.

7 Hess RA, Cooke PS, Bunick D \& Kirby JD. Adult testicular enlargement induced by neonatal hypothyroidism is accompanied by increased Sertoli and germ cell number. Endocrinology $19931322607-2613$.

8 Cooke PS, Hess RA, Kirby JD, Bunick D \& Hardy MP. Neonatal propylthiouracil treatment as a model system for studying factors controlling testis growth and sperm production. In Function of Somatic Cells in the Testis, pp 400-407. Ed. A Bartke. New York: Springer-Verlag, 1994.

9 Palmero S, Maggiani S \& Fugassa E. Nuclear triiodothyronine receptors in rat Sertoli cells. Molecular and Cellular Endocrinology $198858253-256$.

10 Jannini EA, Olivieri M, Francavilla S, Gulino A, Ziparo E \& D'Armiento M. Ontogenesis of the nuclear 3,5,3'-triiodothyronine receptor in the rat testis. Endocrinology 1990126 2521-2526.

11 Jannini EA, Dolci S, Ulisse S \& Nikodem VM. Developmental regulation of the thyroid hormone receptor alpha 1 mRNA expression in the rat testis. Molecular Endocrinology 1994 8 89-96.

12 Ulisse S, Jannini EA, Pepe M, De Matteis S \& D'Armiento M. Thyroid hormone stimulates glucose transport and GLUT1 mRNA in rat Sertoli cells. Molecular and Cellular Endocrinology 199287 131-137.

13 Arambepola NK, Bunick D \& Cooke PS. Thyroid hormone and follicle-stimulating hormone regulate Mullerian-inhibiting substance messenger ribonucleic acid expression in cultured neonatal rat Sertoli cells. Endocrinology $19981394489-4495$.

14 Cooke PS, Zhao YD \& Bunick D. Triiodothyronine inhibits proliferation and stimulates differentiation of cultured neonatal Sertoli cells: possible mechanism for increased adult testis weight and sperm production induced by neonatal goitrogen treatment. Biology of Reproduction 199451 1000-1005.

15 Ulisse S, Rucci N, Piersanti D, Carosa E, Graziano FM, Pavan A et al. Regulation by thyroid hormone of the expression of basement membrane components in rat prepubertal Sertoli cells. Endocrinology $1998139741-747$.

16 Benahmed M. Growth Factors and Cytokines in the Testis. In Male Infertility, pp 55-97. Ed. FH Comhaire. London: Chapman \& Hall Medical, 1995.
17 Jones JI \& Clemmons DR. Insulin-like growth factors and their binding proteins: biological actions. Endocrine Reviews 199516 3-34.

18 Rechler MM \& Clemmons DR. Regulatory actions of insulinlike growth factor binding proteins. Trends in Endocrinology and Metabolism $19989176-183$.

19 Kim KH \& Wang Z. Action of vitamin A on the testis: role of the Sertoli cell. In The Sertoli Cell, pp 517-535. Eds LD Russel \& MD Griswold. Clearwater: Cache River Press, 1993.

20 Palmero S, Benahmed M, Morera AM, Trucchi P \& Fugassa E. Identification of nuclear triiodothyronine receptors in Sertoli cells from immature piglet testes. Journal of Molecular Endocrinology 19929 55-59.

21 Benahmed M, Cochet C, Keramidas M, Chauvin MA \& Morera AM. Evidence for a FSH dependent secretion of a receptor reactive transforming growth factor $\beta$-like material by immature Sertoli cells in primary culture. Biochemical and Biophysical Research Communications 1988154 1222-1231.

22 Palmero S, Bardi G, Bolla F \& Fugassa E. Influence of thyroid hormone on Sertoli cell protein metabolism in the prepubertal pig. Journal of Biological Research 199672 163-170.

23 Mather JP \& Phillips D. Primary cultures of testicular somatic cells. In Methods for Serum-Free Culture of Cells of the Endocrine System, pp 29-45. Eds DW Barnes, DA Sirbasku \& GH Sato. New York: AR Liss, 1984.

24 Chomczynski P \& Sacchi N. Single-step method of RNA isolation by acid guanidinium thiocyanate-phenol-chloroform extraction. Analytical Biochemistry 1987162 156-159.

25 Murphy LJ, Seneviratne C, Bellejo G, Croze F \& Kennedy TG. Identification and characterization of a rat decidual insulin-like growth factor-binding protein complementary DNA. Molecular Endocrinology 19904 329-336.

26 Brown AL, Chiariotti L, Orlowski CC, Mehlman T, Burgess WH, Ackerman EJ et al. Nucleotide sequence and expression of a cDNA clone encoding a foetal rat binding protein for insulin-like growth factor. Journal of Biological Chemistry 1989264 5148-5154.

27 Shimasaki S, Koba A, Mercado M, Shimonaka M \& Ling N. Complementary DNA structure of the high molecular weight rat insulin-like growth factor binding protein (IGF-BP3) and tissue distribution of its mRNA. Biochemical and Biophysical Research Communications 1989165 907-912.

28 Shimasaki S, Uchiyama F, Shimonaka M \& Ling N. Molecular cloning of cDNAs encoding a novel insulin-like growth factorbinding protein from rat and human. Molecular Endocrinology 19904 1451-1458.

29 Shimasaki S, Shimonaka M. Zhang HP \& Ling N. Identification of five different insulin-like growth factor binding proteins (IGFBPs) from adult rat serum and molecular cloning of a novel IGFBP-5 in rat and human. Journal of Biological Chemistry 1991 266 10646-10653.

30 Shimasaki S, Gao L, Shimonaka M \& Ling N. Isolation and molecular cloning of insulin-like growth factor binding protein-6. Molecular Endocrinology 19915 938-948.

31 Chan Y-L, Gutell R, Noller HF \& Wool IG. The nucleotide sequence of a rat $18 \mathrm{~S}$ ribosomal ribonucleic acid gene and a proposal for the secondary structure of $18 \mathrm{~S}$ ribosomal ribonucleic acid. Journal of Biological Chemistry 1984259 224-230.

32 Sambrook J, Fritsch EF \& Maniatis T. Molecular Cloning: a Laboratory Manual, edn 2. Cold Spring Harbor, New York: Cold Spring Harbor Laboratory Press, 1989.

33 Hossenlopp P, Seurin D, Segovia-Quinson B, Hardouin S \& Binoux M. Analysis of serum insulin-like growth factor binding proteins using Western blotting: use of the method for titration of the binding proteins and competitive binding studies. Analytical Biochemistry 1986154 138-143.

34 Rechler MM. Non-receptor-binding proteins for insulin-like growth factors and other cytokines: modulators of peptide action. In Molecular Endocrinology: Basic Concepts and Clinical Correlations, pp 155-180. Ed. BD Weintraub. New York: Raven Press, 1995. 
35 Glantschnig H, Varga F \& Klaushofer K. Thyroid hormone and retinoic acid induce the synthesis of insulin-like growth factorbinding protein-4 in mouse osteoblastic cells. Endocrinology 1996 $137281-286$.

36 Demori I, Bottazzi C, Voci A, Gallo G, Scharf JG \& Fugassa E. Triiodothyronine increases insulin-like growth factor binding protein-4 in rat hepatocytes. Journal of Endocrinology 1997154 155-165.

37 LaTour D, Mohan S, Linkhart TA, Baylink DJ \& Strong DD. Inhibitory insulin-like growth factor-binding protein: cloning, complete sequence, and physiological regulation. Molecular Endocrinology 19904 1806-1814.

38 Adashi EY, Resnick CE, Hurwitz A, Ricciarelli E, Hernandez ER, Roberts CT et al. The ovarian and testicular IGF-I system: a comparative analysis. In Spermatogenesis, Fertilisation, Contraception: Molecular, Cellular and Endocrine Events in Male Reproduction, pp 143-163. Eds E Nieschlag \& UF Habenicht. Berlin: Springer-Verlag, 1992.

39 Smith EP, Svoboda ME, Van Wyk JJ, Kierszenbaum AL \& Tres LL. Partial characterization of a somatomedin-like peptide from the medium of cultured rat Sertoli cells. Endocrinology 1987120 186-193.

40 Oonk RB \& Grootegoed JA. Insulin-like growth factor I (IGF-I) receptors on Sertoli cells from immature rats and age-dependent testicular binding of IGF-I and insulin. Molecular and Cellular Endocrinology 1988 $5533-43$.

41 Borland K, Mita M, Oppenheimer CL, Blinderman LA, Massague J, Hall PF et al. The action of insulin-like growth factors I and II on cultured Sertoli cells. Endocrinology 1984114 240-246.

42 Jaillard C, Chatelain PC \& Saez J. In vitro regulation of pig Sertoli cell growth and function: effects of fibroblast growth factor and somatomedin-C. Biology of Reproduction 198737 665-674.

43 Smith EP, Dickson BA \& Chernausek SD. Insulin-like growth factor binding protein-3 secretion from cultured rat Sertoli cells: dual regulation by follicle stimulating hormone and insulin-like growth factor-I. Endocrinology 1990127 2744-2751.

44 Gallo G, de Marchis M, Voci A \& Fugassa E. Expression of hepatic mRNAs for insulin-like growth factors-I and -II during the development of hypothyroid rats. Journal of Endocrinology 1991 $131367-372$.

45 Nanto-Salonen K, Muller HL, Hoffman AR, Vu TH \& Rosenfeld RG. Mechanism of thyroid hormone action on the insulin-like growth factor system: all thyroid hormone effects are not growth hormone mediated. Endocrinology 1993132 $781-788$.

46 Rodriguez-Arnao J, Miell J, Thomas M, McGregor AM \& Ross RJM. Changes in hepatic insulin-like growth factor-binding proteins-1, -2 and -3 mRNA levels in rats with altered thyroid status. Journal of Endocrinology 1994140 251-255.

47 Frystyk J, Gronbaek H, Skjaerbaek C \& Flyvbjerg A. Effects of hyperthyroidism on circulating levels of free and total IGF-1 and IGFBPs in rats. American Journal of Physiology 1995269 E840-E845.

48 Palmero S, Prati M, Barreca A, Minuto F, Giordano G \& Fugassa E. Thyroid hormone stimulates the production of IGF-1 by rat Sertoli cells. Molecular and Cellular Endocrinology 199068 61-65.

49 Sheikh MS, Shao ZM, Hussain A, Chen JC, Roberts CJ, LeRoith D et al. Retinoic acid and oestrogen modulation of insulin-like growth factor binding protein-4 gene expression and the oestrogen receptor status of human breast carcinoma cells. Biochemical and Biophysical Research Communications 1993193 1232-1238.

50 Berrodin TJ, Marks MS, Ozato K, Linney E \& Lazar MA. Heterodimerization among thyroid hormone receptor, retinoic acid receptor, retinoid $\mathrm{X}$ receptor, chicken ovalbumin upstream promoter transcription factor, and an endogenous liver protein. Molecular Endocrinology $199261468-1478$.

51 Williams GR, Harney JW, Moore DD, Larsen PR \& Brent GA. Differential capacity of wild type promoter elements for binding and trans-activation by retinoic acid and thyroid hormone receptors. Molecular Endocrinology 19926 1527-1537.

52 Gao L, Ling N \& Shimasaki S. Structure of the rat insulin-like growth factor binding protein- 4 gene. Biochemical and Biophysical Research Communications 1993190 1053-1059.

53 Mohan S, Bautista CM, Wergedal J \& Baylink DJ. Isolation of inhibitory insulin-like growth factor (IGF) binding protein from bone cell-conditioned medium: a potential local regulator of IGF action. Proceedings of the National Academy of Sciences of the USA $1989868338-8342$.

Received 27 April 1999

Accepted 2 August 1999 